\title{
REVITALISATION OF AGRICULTURE OF THE REPUBLIC OF SERBIA AS A FACTOR OF ECONOMIC DEVELOPMENT
}

\section{Mihailo Ćurčić ${ }^{1}$, Stefan Slovak ${ }^{2}$, Stevan Mitrović $^{3}$}

\begin{abstract}
Today, in the era of industrial expansion of developing countries, the Republic of Serbia strives to maintain the required level of progress and join the European Union. On this path of transition, it is necessary to use the comparative advantages in relation to the countries of the region, but also the EU member states. Analysing the available data, it can be established that an important comparative advantage of Serbia lies in the agricultural sector. The aim of this paper is to point out the mentioned comparative advantages, primarily by using the historical-comparative method, and to provide a basis for further decision-making to economic policy makers at the regional and national level. The concept of agricultural and economic policy should be based on the complete revival of agriculture, its revitalization, financial consolidation, innovation and affirmation of the intensification of the production framework.
\end{abstract}

Key words: revitalization, economic development, agriculture, Serbia.

JEL $^{4}$ : Q10, Q18

\section{Introduction}

During the past decades, there has been a drastic decrease in the number of agricultural population, which, among other things, has affected the reduction of agricultural production in the Republic of Serbia. Determining factors, in the form of low incomes of the agricultural population, the subordinate position of the rural population and rural areas, and the continuous industrialization of urban areas, initiated the process of rural disappearance (RZS, 2011; RZS, 2020).

By efficiently exploiting the comparative advantages (Avakumović et al., 2021) of national agriculture, Serbia could reach the fullness of economic development (Đorđević, Krstić, 2020) in a short time, based on strong and stable agricultural

1 Mihailo Ćurčić, Ph.D., Assistant Professor, University of Defense, Pavla Jurišića Šturma Street no. 33, 11000 Belgrade, Serbia, Phone: +381 6540090 49, E-mail: curcicmihailo@gmail.com

2 Stefan Slovak, B.Sc., School of Management and Economics, Karađorđeva Street no. 52, 34000 Kragujevac, Serbia, Phone: +381 64535 19 93, E-mail: slovak_knight@yahoo.com

3 Stevan Mitrović, B.Sc., School of Management and Economics, Karađorđeva Street no. 52, 34000 Kragujevac, Serbia, Phone: +381 66330 669, E-mail: 8stevan@gmail.com

4 Article info: Technical Article, Received: $13^{\text {th }}$ July 2021, Accepted: $10^{\text {th }}$ October 2021. 
production, which would, in addition to raw materials, offerhigher processing products, branded or organic agro-food products recognizable in Europe. The marginalization of villages and rural areas in Serbia, as a basic element of agricultural development, has been influenced by numerous historical and social circumstances. They are mainly manifested through the technological obsolescence of the production base, pronounced fragmentation and economic weakening of farms, lack of investment funds, etc., which have resulted in generally low productivity in this sector of the economy (Đurić et al., 2020).

There is a strong view that adequate investment in the comparative advantages of national agriculture would nullify the negative effects of most socio-economic trends, which over the past three decades have led to an outflow of labour (brain drain) and impoverishment of both agriculture and rural areas.

\section{Methodology}

During the research, for the purposes of monitoring and analysis of selected macro indicators, the historical-comparative method, as well as desk research and deduction methods was used. The methodological framework used allows for an overview of the current state of the agricultural sector in Serbia, and supports the adoption of adequate conclusions that would trigger a mechanism for the sustainability of its development.

The research is based on secondary data that mostly cover the period of the last twenty years. The context and structure of the research are harmonized with the used data of the Republic Bureau of Statistics, and the appropriate scientific and professional literature. For better understanding, all monitored indicators are presented in tables or graphs.

\section{Agro-economic Aspects of National Agriculture's State}

In 2000, over 2.9 million employees were registered, of which more than 840 thousand were registered as active in the agricultural sector. On the other hand, in the same year there were over 500 thousand unemployed persons at the national level (RZS, 2004). By 2010, there will be pronounced structural changes in the labour market, which to some extent affect the intensity and continuity of the outflow of the rural population towards urban areas, i.e. predominantly abroad. In ten years, the number of employed persons decreased by more than 525 thousand (to about 2.4 million persons), the number of employees in the agricultural sector decreased by over 307 thousand, while the number of unemployed increased by almost 70 thousand (RZS, 2011). The latest cross-section of national statistics (RZS, 2020) shows the continued presence 
of this trend, as in 2019 the number of employees was further reduced to about 2.1 million, while the number of employees in the agricultural sector was further reduced to about 450 thousand. In the same period, there was a significant decline in the number of unemployed to about 336 thousand (Table 1).

Table 1. Employees in the Agricultural Sector

\begin{tabular}{|c|c|c|c|}
\hline Year & Total Employed & $\begin{array}{c}\text { Employees in the } \\
\text { Agricultural Sector }\end{array}$ & Unemployed \\
\hline $\mathbf{2 0 0 0}$ & $2,918,589$ & 840,050 & 500,325 \\
\hline $\mathbf{2 0 1 0}$ & $2,396,244$ & 532,969 & 568,723 \\
\hline $\mathbf{2 0 1 9}$ & $2,101,267$ & 452,700 & 335,900 \\
\hline
\end{tabular}

Source: RZS, 2004, 2011, 2020.

It should be noted that there are approximately 600 thousand agricultural holdings in Serbia, of which only about 53\% are entered in the Register of Agricultural Holdings (Jeločnik et al., 2021). The declining trend in the number of agricultural holdings is to some extent in line with developments in the national labour market. The decline in the number of employees in the observed period is largely the result of the outflow of skilled labour and the distortion of the populations' age pyramid.

Agricultural land in the Republic of Serbia is mostly privately owned (Trivić, 2021). During the last two decades, there has been a noticeable transition within the ownership structure of agricultural land, with the growth of private ownership from $80 \%$ in 2002 to $83 \%$ in 2010, and as much as $96 \%$ in 2019 (Prodanović et al., 2017). On the other hand, in the previous period, a change in the structure of plant production is noticeable, i.e. an increase in the fund of arable land can be noticed, primarily at the expense of areas under pastures. Table 2 . shows the agricultural land by use categories.

Table 2. Agricultural Land by Categories of Use (in $000 \mathrm{ha}$ )

\begin{tabular}{|l|r|r|r|r|r|r|}
\hline \multirow{2}{*}{ Year } & \multirow{2}{*}{ Total } & \multicolumn{4}{|c|}{ Arable Land } & \multirow{2}{*}{ Pastures } \\
\cline { 3 - 6 } & & $\begin{array}{c}\text { Arable Land \& } \\
\text { Gardens }\end{array}$ & Orchards & Vineyards & Meadows & \\
\hline $\mathbf{2 0 0 0}$ & 5,107 & 3,356 & 245 & 71 & 587 & 815 \\
\hline $\mathbf{2 0 1 0}$ & 5,092 & 3,295 & 240 & 57 & 624 & 836 \\
\hline $\mathbf{2 0 1 9}$ & 5,407 & 4,527 & 184 & 21 & 346 & 329 \\
\hline
\end{tabular}

Source: RZS, 2004, 2011, 2020.

From the point of view of used agro-mechanization, according to official statistics (RZS, 2020), the national agriculture sector has about 450 thousand two-axle tractors, where one tractor covers in average 7.69 ha of privately owned agricultural land. One of the problems that agriculture faces is the lack, i.e. obsolescence 
of agricultural mechanization (Petrović, Grujović, 2002). More than 90\% of agricultural machines are older than ten years, which to a greater extent prevents the technological progress of the production process and increases production costs (Đurić, Njegovan, 2016). Generalizing, the production of a certain arable crop employs a farmer for about 20 days a year cumulatively. Similarly, animal husbandry is a sector that requires the constant presence of farmers on the farm. In 2019, the ratio of crop production to livestock in the structure of the total value of agricultural production was $66: 34 \%$. As a reflection of the level of agricultural development, the share of livestock in total agricultural production in the EU is about 70\% (Domazet et al., 2018; Živković et al., 2019), there is a need to change the overall structure of agricultural production, in order to encourage growth in livestock in national agriculture.

Table 3. Livestock production (in 000 head)

\begin{tabular}{|c|c|c|c|c|}
\hline Year & Cattle & Pigs & Sheep & Poultry \\
\hline $\mathbf{1 9 8 0}$ & 2,367 & 2,415 & 2,045 & 13,248 \\
\hline $\mathbf{1 9 9 0}$ & 1,979 & 2,444 & 1,805 & 14,205 \\
\hline $\mathbf{2 0 0 0}$ & 1,299 & 2,536 & 1,463 & 13,351 \\
\hline $\mathbf{2 0 1 0}$ & 1,002 & 3,631 & 1,504 & 22,821 \\
\hline $\mathbf{2 0 1 9}$ & 898 & 2,903 & 1,642 & 15,780 \\
\hline
\end{tabular}

Source: RZS, 2004, 2011, 2020.

According to Table 3, a rapid decline in the number of cattle over the last few decades can be observed. Compared to the 80 's, the number of sheep has also decreased, which is mainly a consequence of their extensive breeding on pastures, most often without the application of modern technology. Modernization and intensification of sheep breeding would help the development of this branch and overall agriculture, enabling the placement of specific products on international markets. Like global trends, the increase in the number of heads of other livestock species (primarily pigs and poultry) is a consequence of lower prices of fresh meat and processed products, which initiated the growth of demand for these agro-food products on the world market (Galloway et al., 2007; Vukasovič, 2014).

Agricultural production is a significant sector of the Serbian economy (Kuzman et al., 2017), which participates with about $6 \%$ in the creation of national GDP. However, according to the available resources, there is obviously a discontinuity in the optimization of the use of agricultural potentials, which is evident from the oscillations shown in Figure 1. 
Figure 1. Agricultural Production (in millions of RSD)

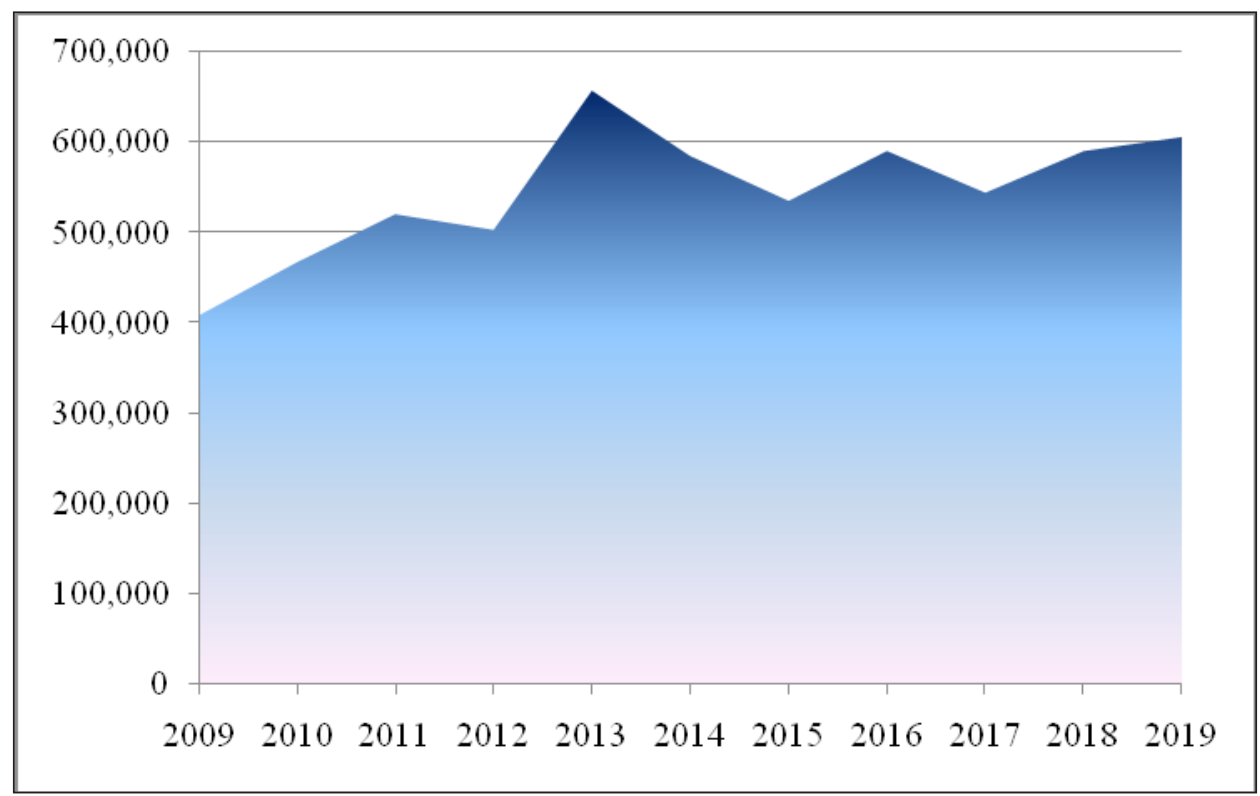

Source: RZS, 2011, 2020.

Looking at the available data for the last three years, there is a stagnant share of agricultural production in total GDP (about 6\%), as well as an increase in the foreign trade surplus of agricultural sector (about 260 million USD in 2017, about 368 million USD in 2018 and about 508 million USD in 2019). What does not support the presented are large oscillations in the real growth rate of agricultural production in the given years (-11.4 in 2017, 15.1 in 2018, and -1.6 in 2019), (RZS, 2020). According to the results of the research (Marković et al., 2019), at the national level there is definitely a problem of poor structure and low intensity of agricultural production, which favours crop (crop production dominates within crop production) over livestock production, with a current ratio of 2:1. Moreover, it has been shown that the total value of livestock production has a small impact on the realization of GVA of national agriculture, with significant cost burden, unrealistically low prices of animal products and low level of public support contributing to the collapse of this agricultural sector (Novaković, 2019). Proven principles of long-term agricultural sustainability require a change in the production structure in favour of more intensive branches and lines of agricultural production.

\section{Results and Discussion}

After three decades of structural changes, Serbia is a developing country with the status of a candidate for EU membership, which significantly defined its 
development policy. Based on the presented data, it is considered that the revival of national agriculture (specifically with the expansion to the agro-industry) is one of the key elements of sustainable economic development of Serbia. Moreover, the motivation of the population (especially the younger population) to form or relocate their household to the rural environment should be the main trump card in implementing the revitalization of agriculture and rural communities. This would be achieved by significant investments in the village (elements of social and physical infrastructure) and agricultural production (modernization of machinery, equipment and technology), which would create an adequate business and living environment in rural areas (Berjan et al., 2015).

From the point of view of creating the necessary preconditions for revitalization, several weak points of Serbian agriculture were identified (Simonović et al., 2012; Veličković, Jovanović, 2021): small and fragmented farm holdings, poor production structure, generally low yields and small production volume, small irrigated areas, lack of infrastructure elements, general shortage of cooperatives and producer associations, uncertainty of sales channels, production based on experience rather than implementation of innovations and strict adherence to the principles of good agricultural practice, lack of certification, poor age and educational structure of farmers, depopulation of rural areas, limited investment activity, lack of processing and value added, and more.

According to some estimates, by 2032, Serbia should defend over a million hectares of the most fertile land from the effects of drought (Marković, Kokot, 2019; Stričević et al., 2020). It is estimated that today about $12 \%$ of the total number of agricultural farms irrigate about 3\% of the used agricultural land (Ponjičan et al., 2017).

However, the wider implementation of irrigation implies an adequate structure of crop production and access to sustainable land use (Subić et al., 2017). There are some opinions (Đurić, Njegovan, 2016) that national agriculture is not able to follow modern trends by using extensive industrialization. It is necessary to overcome the problems of low productivity, insufficient use of renewable resources and renewable energy sources in production, that is, high technological dependence on developed countries. An important contribution to the growth of agricultural production and productivity can provide the use of modern management methods, adequate resource allocation, application of industrial engineering and production planning techniques, improving the quality of human resources, energy accumulation, investment planning, implementation of information systems, etc.

It should be noted that agriculture is also rapidly adapting to the post-industrial or digital revolution and knowledge-based development. Achieving the sustainability 
of agriculture today is harmonized with an adequate level of its intensification, which targets increased productivity with minimal impact on the living environment, as well as with the provision of social benefits. Today, in the era of the fourth industrial revolution, agriculture is striving to implement advanced technologies, which significantly change the perception of the concept of agricultural production and rural areas. In addition to this, the frequent linking of accumulated knowledge in agriculture primarily with IT and biotechnology, leads to its equating with some of the high-tech sectors (Partoyo, 2019). The mentioned efforts are also applied in Serbian agriculture (Bešić et al., 2021).

In line with the previous, the appropriate education of persons involved in the chain of movement of agro-food products from "field to table" paves the way, not only for efficient management of farms, but also for effective use of EU funds intended for agricultural development. Also, in the conditions of national agriculture, it has been shown that subsidies are essential for its further development, and often survival. Unfortunately, although Serbia is the regional leader in the realized transfers, it is noticed that the current level of direct payments and subsidies to households is lower in relation to the EU members. One of the frequent recommendations is to intensify the aspiration to equalize, at least the relative level of national and EU subsidies (52\% of the budget), and strengthen the distribution of grants, as well as more favourable programming of credit lines focused on agriculture (reduction of interest rates and short-term and long-term loans longer grace period), (Nacionalni tim za preporod sela Srbije, 2020).

In terms of transitional reforms, the first decade of the $21^{\text {st }}$ century in Serbia can be divided into two phases. During the first, most of the process of privatization and restructuring of vital parts of the economy was carried out, with the start of the EU accession process. The second phase is characterized by an emphasis on creating a stimulating economic environment, and changes in the tax system and the public sector (VRS, 2014)

One of the most important roles in planning and implementing the process of revitalization of agriculture and rural areas should be played by local self-government units, as autonomous management systems for local communities. Also, as a mediator between public administration and rural areas, local governments should harmonize and direct local action plans with defined national priorities.

Activities of revitalization of Serbian villages, and moreover agriculture, should be reflected in the following (Pejanović et al., 2017): motivating young people to stay, return or come to rural areas to establish farms; more pronounced contributions to the development of rural infrastructure; subsidizing primarily domestic investors 
who invest in agricultural and non-agricultural activities in rural areas; ensuring the competitiveness of agricultural and food products in national and foreign markets; professional and educational guidance of human capital engaged in agriculture; support for the strengthening of cooperatives; and more.

\section{Conclusion}

A review of the state of national agriculture over the past few decades from the point of view of agro-economy, identifies several main problems: there is definitely a downward trend in the number of employees in the agricultural sector and a decline in the number of agricultural holdings. Also, the transition of the ownership structure over agricultural farms and land is evident, which in a way initiated a discontinuity in the optimization of the use of agricultural potentials and resources. Today, it is present through indicators with a negative effect on the competitiveness of national agriculture and agro-food products, such as outdated technical-technological base, inefficient use of available resources and production inputs, which find a logical alternative in efficient modernization of agriculture (Ćurčić et al., 2021).

Primarily, the basic direction of the national agriculture efficient revitalization process implementation is reflected in the development of human resources, ie in the motivation of young people for a mass return to rural areas. This would directly affect the growth of investments in the sustainability of production, as well as in rural physical and social infrastructure (such as roads, water supply, electrification, implementation of sewerage and telecommunications network, construction of clinics, schools, cultural centres, etc.). It would certainly contribute to the modernization of agriculture and strengthen the position of farmers, while ensuring the growth of their competitiveness and more efficient management of available resources, as well as better use of comparative advantages in relation to the region. Also, other non-agricultural activities would be developed in parallel, generally leading to the improvement of living conditions in the countryside.

\section{References}

1. Avakumović, J., Tešić, R., Karić, D. (2021). Menadžment tranzicionim procesima u funkciji održivog razvoja. Održivi razvoj, 3(1):7-16.

2. Berjan, S., El Bilali, H., Janković, S., Radosavac, A. (2015). Upravljanje i koordinacija poljoprivrednog i ruralnog razvoja u Bosni i Hercegovini. Ekonomika poljoprivrede, 62(1):95-106.

3. Bešić, C., Bakator, M., Đorđević, D., Ćoćkalo, D. (2021). Agriculture 4.0 and improving competitiveness of the agro-food sector. Ekonomika poljoprivrede, 68(2):531-545. 
4. Curčić, M., Todorović, V., Dakić, P., Ristić, K., Bogavac, M., Špiler, M., Rosić, M. (2021). Economic potential of agro-food production in the Republic of Serbia. Ekonomika poljoprivrede, 68(3):687-700.

5. Domazet, S., Jotić, J., Ješić, J. (2018). Državna pomoć za ruralni razvoj u Evropskoj uniji. Poslovna ekonomija, 12(2):90-110.

6. Đorđević, D., Krstić, D. (2020). Odnos fiskalne politike i održivog razvoja. Održivi razvoj, 2(1):7-15.

7. Đurić, K., Njegovan, Z. (2016). Ekonomika poljoprivrede. Poljoprivredni fakultet, Univerzitet u Novom Sadu, Srbija.

8. Đurić, K., Prodanović, R., Čavlin, M., Lukač Bulatović, M. (2020). Ekonomske performanse agroindustrije u AP Vojvodini. Oditor, 6(2):7-19.

9. Galloway, J., Burke, M., Bradford, G., Naylor, R., Falcon, W., Chapagain, A., Gaskell, J., McCullough, E., Mooney, H., Oleson, K., Steinfeld, H., Wassenaar, T., Smil, V. (2007). International trade in meat: the tip of the pork chop. Ambio, 36(8):622-629.

10. Jeločnik, M., Subić, J., Nastić, L. (2021). Upravljanje troškovima na poljoprivrednim gazdinstvima. Institut za ekonomiku poljoprivrede, Beograd, Srbija.

11. Kuzman, B., Đurić, K., Mitrović, Lj., Prodanović, R. (2017). Agrarni budžet i razvoj poljoprivrede u Republici Srbiji. Ekonomika poljoprivede, 64(2):515-531.

12. Marković, M., Milanović, S., Marjanović, I. (2019). Strukturna prilagođavanja i održivost poljoprivredne proizvodnje u Srbiji. Ekonomija održivog razvoja, 3(2):39-48.

13. Marković, T., Kokot, Ž. (2019). Osiguranje kao finansijski instrument u upravljanju rizicima u poljoprivredi. Ratarstvo i povrtarstvo, 56(1):7-12.

14. Nacionalni tim za preporod sela Srbije (2020). Nacionalni program za preporod sela Srbije: stanje, problemi i prioriteti održivog razvoja. Institut za ekonomiku poljoprivrede, Beograd, Srbija.

15. Novaković, T. (2019). Analiza Bruto Dodate Vrednosti poljoprivrede u Republici Srbiji. Ekonomske ideje i praksa, 32:39-55.

16. Partoyo, P. (2019). Farming in the Era of Industrial Revolution 4.0: The Environmental Challenges. Proceeding International Conference on Green Agro-Industry, 4(1):27-38.

17. Pejanović, R., Glavaš Trbić, D., Tomaš Simin, M. (2017). Problem i razvoja poljoprivrede i sela Republike Srbije i nužnost nove agrarne politike. Ekonomika poljoprivrede, 64(4):1619-1633.

18. Petrović, G., Grujović, M. (2015). Connections and economic importance of agriculture and rural tourism. Ekonomski signali: Poslovni magazin, 10(1):56-63. 
19. Ponjičan, O., Bugarin, R., Sedlar, A., Turan, J., Višacki, V., Stanić, N. (2017). Stanje i pravci razvoja navodnjavanja u svetu i kod nas. Savremena poljoprivredna tehnika, 43(4):147-157.

20. Prodanović, R., Nedeljković, M., Škorić, M. (2017). Pravni režimi njegov uticaj na razvoj porodičnih poljoprivrednih gazdinstava u Republici Srbiji i Republic i Srpskoj. Ekonomija: teorija i praksa, 10(1):67-79.

21. RZS (2004). Statistički godišnjak Republike Srbije: 2004. Republički zavod za statistiku (RZS), Beograd, Srbija.

22. RZS (2011). Statistički godišnjak Republike Srbije: 2011. Republički zavodzastatistiku (RZS), Beograd, Srbija.

23. RZS (2020). Statistički godišnjak Republike Srbije: 2020. Republički zavod za statistiku (RZS), Beograd, Srbija.

24. Simonović, Z., Jeločnik, M., Vasić, Z. (2012). Economic Position of Serbian Agriculture in the Transition Period. Ekonomika poljoprivrede, 59(3):535-545.

25. Stričević, R., Lipovac, A., Prodanović, S., Risovski M., PetrovićObradović, O., Đurović, N., Đurović, D. (2020). Vulnerability of agriculture to climate change in Serbia: Farmers' assessment of impacts and damages. Journal of Agricultural Sciences, 65(3):263-281.

26. Subić, J., Kljajić, N., Jeločnik, M. (2017). Obnovljivi izvori energije $i$ navodnjavanje u funkciji održivog razvoja poljoprivrede: Ekonomski aspekti. Institut za ekonomiku poljoprivrede, Beograd, Srbija.

27. Trivić, N. (2021). Raspoložive poljoprivredne površine i vlasnička struktura gazdinstava u Republici Srbiji. Ekonomika poljoprivrede, 68(2):291-305.

28. Veličković, J., Jovanović, S. (2021). Problemi mogući pravci održivog razvoja ruralnog razvoja Republike Srbije. Ekonomija održivog razvoja, 5(1):33-46.

29. VRS (2014). Strategija poljoprivrede i ruralnog razvoja Republike Srbije za period 2014-2024. godine. Vlada Republike Srbije (VRS), Službeni glasnik RS, br. $85 / 14$.

30. Vukasovič, T. (2014). European meat market trends and consumer preference for poultry meat in buying decision making process. World's Poultry Science Journal, 70(2):289-302.

31. Živković, A., Pantić, N., Rosić, M. (2019). Fiskalna održivost makroekonomskog sistema članica Evropske unije. Oditor, 5(2):32-41. 